\title{
Effect of Corporate Social Responsibility and Good Corporate Governance on the Value of Company with Profitability as Moderating Variables
}

\author{
Ery Yanto \\ erymulyadi@yahoo.com \\ Accounting Study Program, Faculty of Bussiness \\ Universitas Presiden, Cikarang, Indonesia
}

\begin{abstract}
This research aims to examine the influence of disclosure of corporate social responsibility and good corporate governance on the firm value to profitability as a moderating variable of manufactured companies listed on the Indonesia Stock Exchange for the period 2010-2012. This type of research is an association research using purposive sampling technique. The population in this study are the manufactured companies listed on Indonesia Stock Exchange during the years 2010-2012, as many as 91 companies as selected samples, thus, the total of observations in this study is composed of 273 companies that are analyzed using multiple linear regression with moderate regression analysis. The data used are from financial statements and sustainable report. Hypothesis testing using t test and $\mathrm{F}$ test. Research results showed that disclosure of corporate social responsibility and good corporate governance that is moderated affects firm value.
\end{abstract}

Keywords: corporate social responsibility, good corporate governance, firm value, profitability 


\title{
Pengaruh Tanggung Jawab Sosial Perusahaan dan Tata Kelola Perusahaan yang Baik terhadap Nilai Perusahaan dengan Profitabilitas sebagai Variabel Pemoderasi
}

\author{
Ery Yanto \\ erymulyadi@yahoo.com \\ Accounting Study Program, Faculty of Business \\ Universitas Presiden, Cikarang, Indonesia
}

\begin{abstract}
Intisari
Penelitian ini bertujuan untuk menganalisi pengaruh pengungkapan tanggung jawab sosial perusahaan dan Good Corporate Governance terhadap nilai profitabilitas perusahaan sebagai variabel moderasi untuk perusahaan manufaktur yang terdaftar di Bursa Efek Indonesia selama periode 2010-2012. Jenis penelitian ini adalah penelitian asosiasi dengan menggunakan teknik analisis purposive sampling. Populasi dalam penelitian ini adalah perusahaan manufaktur yang terdaftar di Bursa Efek Indonesia selama tahun 2010-2012. Sampel yang diambil sebanyak 91 perusahaan sehingga total pengamatan dalam penelitian ini berjumlah 273 observasi. Analisis menggunakan regresi linier berganda. Data yang digunakan bersumber dari laporan keuangan dan laporan berkelanjutan. Pengujian hipotesis menggunakan uji t dan uji $\mathrm{F}$. Hasil penelitian menunjukkan bahwa pengungkapan tanggung jawab sosial perusahaan dan Good Corporate Governance yang dimoderasi mempengaruhi nilai perusahaan.
\end{abstract}

Kata kunci: tanggung jawab sosial perusahaan, tata kelola perusahaan yang baik, nilai perusahaan, profitabilitas 


\section{INTRODUCTION}

Corporate social responsibility (CSR) is not a new concern in the scope of Indonesian companies. This can be seen in the contribution of costs allocated to the development of the local environment in which the company operates. It is just that the fulfillment of the cost obligations for local environmental development is only voluntary. For companies in developed countries like the United States and Europe, social responsibility activities are so important for profitability and financial success. In the United States, about ten per cent of capital is invested into social responsibility activities (Social Investment Forum, 2010). In addition, more than 60 global financial institutions have adopted the principle of equator, a code of conduct that incorporates social and environmental criteria into large project financing decisions (Equatorial Principles, 2006). As a result, the demand and supply of CSR information increased rapidly (Holder-Webb et al., 2009). Approximately $80 \%$ of the world's biggest companies and $73 \%$ of the largest companies in United States, issued a CSR report independently, in addition to annual financial reports (KPMG, 2008).

Despite the important role of CSR in today's business environment, there is a substantial debate over how it affects financial performance. Critics claim that CSR may be the attention of management spreading into projects with uncertain future benefits, allocating resources that could be better invested elsewhere (Karnani, 2010).

The concept of good corporate governance is based on the problem of separation between ownership and management within the company, which is then modeled with agency theory. In the mechanism of good corporate governance, the separation between ownership and control of the company is a very important effort to realize good corporate governance. Riyanto and Toolsema (2007) who examine corporate social responsibility within the framework of good corporate governance illustrate how the social responsibility of shareholders and the threat of pressure by activists affects the stress level of directors and shareholders, given that CSR can enable shareholders to commit to reduce supervisory efforts and may cause managers to work and strive to increase profits as high as possible so as to help solve agency problems.

CSR has a close relationship with good corporate governance. Like two sides of the coin, both have a strong position in the business world but are in touch with each other. CSR is oriented towards the stakeholders this is in line with one of the principles of the four main principles of good corporate governance that is responsibility. The problem of business ethics and business accountability is increasingly getting public attention in some developed countries, which is usually very liberal in dealing with firms is beginning to sound that because "self-regulation" seems to fail, new regulations are required that will provide "higher standards for corporate practice" and "tougher penalties for executive misconduct". Disclosure to the social aspect, ethical, environmental and sustainability have now become a way for companies to communicate the form of accountability to stakeholders. Sustainability reporting as recommended by the Global Reporting Initiative focuses on three aspects of performance that are economic, environmental and social ones. These three aspects are known as Triple Bottom Line. This form of reporting is expected to have a positive relationship between CSR, good corporate governance and the value of the company.

The company will disclose an information if the information can increase the value of the company. Companies can use corporate social responsibility information as a competitive advantage of the company. Companies that have good environmental and social performance will respond positively by investors through an increase in stock prices. If the company has poor environmental and social performance, then there will be doubt from investors so that it responded negatively through the decrease of share price (Almilia et al., 2007). Disclosure of 
CSR and disclosure of good corporate governance in Indonesia is no longer a voluntary disclosure, but it has become a liability because there is already a legal basis.

\section{LITERATURE REVIEW}

\section{Corporate Social Responsibility}

In a global context, the term corporate social responsibility was first proposed in 1953 by Howard Botton explaining what responsibilities one would expect in a company (Garriga \& Mele, 2004 and Simon \& Fredrik, 2009). The development of three important components of sustainable development, namely economic growth, environmental protection, and social equity, in the idea of The World Commission on Environment and Development (WCED) (1987), Elkington (1998) package corporate social responsibility into three focuses: 3P, stands for profit, planet and people. Good companies are not just pursuing a mere economic profitrather it also has concern for the preservation of the environment (the planet) and the welfare of the people (people) (Suharto, 2008).

Anggraini (2006) states that the demand for companies to provide transparent information, accountable organizations and good corporate governance forces companies to provide information for their social activities. The public needs information on the extent to which the company has carried out its social activities so that the right of people to live safe and secure, the employee's welfare, and the safety of consuming food can be fulfilled.

The disclosure of CSR often referred to as social disclosure, corporate social reporting, social accounting (Mathews, 1995) or corporate social responsibility (Hackston \& Milne, 1996) is the process of communicating the social and environmental impacts of an organization's economic activities on a specific group concerned and towards society as a whole. It extends the responsibility of the organization (especially the company), beyond its traditional role to provide financial statements to the owners of capital, especially shareholders. The expansion is made on the assumption that firms have wider responsibilities than simply looking for shareholder returns (Gray et al., 1987).

The meaning of CSR according to ISO 26000 (2010) are: "Responsibility of an organization for the impacts of its decisions on society and the environment, through transparent and ethical behavior that contributes to sustainable development, including health and the welfare of society; takes into account the expectations of stakeholders; is in compliance with applicable law and consistent with international norms of behavior; and is integrated throughout the organization and practiced in its relationship".

The definition of CSR today is very diverse. According to the World Business Council for Sustainable Development (WBCSD), corporate social responsibility is a business commitment to contribute to sustainable economic development, through cooperation with employees and their representatives, their families, local communities and the general public to improve the quality of life by a useful way for both business and development.

Most argue that CSR is a business operation committed not only to increase corporate profits financially but also to approach CSR. Some other names that have similarities and even often identified with CSR is corporate giving, corporate philanthropy, corporate community relations and community development.

Judging from the motivation, these four meanings can be interpreted as dimensions or approach of CSR. Corporate giving charity, corporate philanthropy with humanitarian motive, corporate community relations, and dissemination of charm, for community development are more cultural nuance. In the global context, the term CSR was used since the 1970s and is becoming more popular, especially after the presence of the book cannibals with forks: The Triple Bottom Line in $21^{\text {st }}$ Business (Elkington, 1998). Developing three important components of suitability development includes namely economic growth, 
environmental protection, and social equity. Elikington (1998) summarizes CSR into three focuses: 3P (profit, people, and planets). Good company not only put mere economic profit (profit), but the company must also have a concern for example where the environment (planet) and society (people).

In Indonesia, the term CSR is increasingly popular in use since the 1990s. Although not named as CSR, in fact its action approached the concept of CSR which presented the company's "participation" and "concern" to the social and environmental aspects. The development of the concept of CSR in various national companies is more on the corporate social awareness based on the reason that the company's activities bring good impacts and adverse impacts on the environmental and socio-economic conditions of the community, especially around the company operate. The true owners of the company are not just shareholders, but also interested parties to the extension of the company, such as employees and their families, customers, suppliers, communities around the company, NonGovernmental Organizations (NGOs), mass media, and government as regulators.

Factors influencing the implementation and disclosure of corporate social responsibility are among other political economy theory, legitimacy theory, and stakeholder theory (Deegan, 2002). Meanwhile, according to Roberts (1992), political theory and social contexts are important factors that influence the decision to disclose corporate social responsibility information. Haigh and Jones (2006) revealed that there are six factors that influence corporate social responsibility practices by the company. The six factors are internal pressures on business managers, pressures from business competitors, investors and consumers, and regulatory pressures coming from government and non-governmental organizations.

\section{Legitimacy Theory}

The theory of legitimacy is the foundation of the company's disclosure of CSR because the theory of legitimacy is seen as a prespective orientation system, that the company can influence or be influenced by the community where the company performs activities according to Deegan (2004), the theory of legitimacy confirms that the company continues to make sure that they operate within the frames and norms that exist in the society or environment in which the company is located, where they seek to ensure that their activities are accepted by outsiders as "legitimate".

\section{Stakeholder Theory}

Stakeholders are all parties both internal and external parties who have good relationships are influential or influenced, are direct or indirect (Retno, 2012). The above stakeholder constraints imply that companies should pay attention to stakeholders, as they are the parties that influence and are influenced both directly and indirectly over activities and policies taken and conducted by the company. If companies do not pay attention to stakeholders it is not likely to reap protests and can eliminate stakeholder legitimacy (Adams, 2002)

According to Gozali and Chariri (2007) in stakeholder theory said that the company is not an entity that only operates for its own interests but must provide benefits for its stakeholders (shareholders, creditors, consumers, suppliers, government, community, analysts, and others). Thus, the existence of a company is strongly influenced by the support provided by stakeholders to the company.

\section{Ownership Structure}

The structure of ownership (ownership structure) is the ownership structure, the ratio of the number of shares held by 'insiders' with the number of shares held by investors. In other 
words, the share ownership structure is the proportion of institutional ownership, management ownership, and foreign ownership in the ownership of the company's shares. In carrying out its activities, a company is represented by directors (agents) appointed by shareholders (principals).

\section{Managerial Ownership}

According to Downes and Goodman (1999) and Murwaningsari (2009), managerial ownership is the shareholders which also means in this case as the owner in the company of the management who actively participate in decision making in a company concerned. In agency theory it is explained that the interests of management and the interests of shareholders may be contradictory. This is because managers prioritize personal interests, whereas shareholders do not like the manager's personal interests, because these expenses will increase the company's costs that lead to a decrease in corporate profits and the decrease of dividends to be received. With improved managerial ownership can better align the interests of managers and shareholders, so as to increase the value of the company. Managerial ownership affects the firm's value (Nurlela \& Islahuddin, 2008).

\section{Institutional Ownership}

Institutional ownership is the ownership of shares by parties in the form of institutions such as foundations, banks, insurance companies, investment companies, pension funds, and companies in the form of a company (PT). Institutions typically can control majority shares because they have more resources than other shareholders. Because of the controlling of majority share, the institutional party can supervise the management policy more strongly than other shareholders. If efficient earnings management, high ownership of the property will improve the management of profit but if the company's profit management is opportunistic then high institutional ownership will reduce earnings management (Herawaty \& Vinola, 2008).

Institutional ownership in large proportions also affects firm value. The value of a company can increase if the institution is able to become an effective monitoring tool. The results of Bjuggren et al., (2007), found that institutional ownership affects the company's performance.

\section{Independent Commissioner}

Board of commissioners as the culmination of the company's internal management system has a role to supervise activities. Independent commissioners have high accountability in the conduct of supervision, the better the supervision of a company the better the quality of the disclosure of information submitted. Rustiarini (2010) shows that independent commissioners positively influence the value of the company.

\section{Profitability}

The relationship between the financial performance of an enterprise and the disclosure of social responsibility according to Belkaoui and Karpik (1989) is best expressed with the view that the social response demanded from management equals the capability required to make a firm profit. As stated by Alexander and Bucholdz (1978) that conscious management and attention to social problems will also propose the capabilities necessary to drive the company's financial performance. Consequently, companies that have a social response in relation to social responsibility disclosure should exclude a person who does not respond to the relationship between firm profitability and accounting variables such as investment rate returns and market variables such as differential stock return prices (Sembiring, 2003). 


\section{Factors Affected Corporate Value}

Several previous studies, showing the factors that affect CSR and good corporate governance, in this study categorized sebegai control variables. The control variables in question are firm size, leverage, and audit quality. The need for control variables in this study to control or eliminate any particular effect on the research model. The three components of the control variable selected to test empirically, the extent to which these variables can control the relationship between CSR to firm value and the relationship between GCG and firm value. Company size is related to CSR implementation and disclosure, leverage is related to company value and audit quality related to GCG.

\section{Hipotesis Development}

H1: corporate social responsibility has a positive effect on corporate value

$\mathrm{H} 2 \mathrm{a}$ : institutional ownership positively affects company value

$\mathrm{H} 2 \mathrm{~b}$ : managerial ownership positively affects company value

$\mathrm{H} 2 \mathrm{c}$ : independent commissioner positively affects the value of the company

H3 : there is a positive effect of institutional ownership on firm value with profitability as moderating variable

$\mathrm{H} 4 \mathrm{a}$ : there is a positive effect of institutional ownership on firm value with profitability as moderating variable.

$\mathrm{H} 4 \mathrm{~b}$ : there is a positive effect of managerial ownership on firm value with profitability as moderating variable.

$\mathrm{H} 4 \mathrm{c}$ : there is a positive influence of the independent commissioner on the value of firms with profitability as moderating variables.

\section{RESEARCH METHOD}

The research will be conducted in a structured research phase through good stages of research. The initial phase starts from the population, identification of variables, operational definitions, sources and techniques of data collection as well as subsequent determination of model analysis. This model of analysis will be used as a tool in testing hypotheses proposed in the study to draw research conclusions. This research will observe the direct influence of independent variable that is CSR and corporate governance to dependent variable that is company value by using firm size control variable, leverage, and audit quality.

\section{Data Collection and Sample}

The population in this study are all manufacturing companies listed on Indonesia Stock Exchange (IDX) during the year 2010 to 2012 as many as 91 companies for 3 years amounted to 273 companies. The selection and collecting of sample data required in this research is purposive sampling approach, that is sampling based on certain criteria and criteria used can be based on judgment or based on certain quota (Erlina, 2008), those criteria used are as follows:

1. Registered Manufacturing Company (go public) listed on Indonesia Stock Exchange (IDX) from the period 2010-2012.

2. Have complete financial report and financial report (Annual Report) from 2010 to 2012.

3. Annual reports can be obtained or accessed from the internet.

4. The type of data used in this study is secondary data obtained from financial statements and annual companies listed on Indonesia Stock Exchange during the period 2010-2012.

\section{Research Method}

This study was conducted to analyze the factors that affect the value of the company. 
With the determining factors among others Corporate Social Responsibility (CSR) and Corporate Governance (KI, KM \& KId) using Multiple Regression Linear method. The data already available will be processed using SPSS 21 software.

The model used in this research is multiple regressionas stated below:

$$
\begin{aligned}
\text { TOBQ }_{\mathrm{t}}= & \alpha_{0}+\beta_{1} \mathrm{CSR}_{\mathrm{t}}+\beta_{2} \mathrm{KI}_{\mathrm{t}}+\beta_{3} \mathrm{KM}_{\mathrm{t}}+\beta_{4} \mathrm{KId}_{\mathrm{t}}+\beta_{5} \mathrm{CSR}_{\mathrm{t}} * \operatorname{Prf}_{\mathrm{t}}+\beta_{6} \mathrm{KI}_{\mathrm{t}} * \operatorname{Prf}_{\mathrm{t}}+\beta_{7} \mathrm{KM}_{\mathrm{t}} * \operatorname{Prf}_{\mathrm{t}}+ \\
& \beta_{8} \mathrm{KId}_{\mathrm{t}} * \operatorname{Prf}_{\mathrm{t}}+\beta_{9} \mathrm{FZ}_{\mathrm{t}}+\beta_{10} \mathrm{LEV}_{\mathrm{t}}+\beta_{11} \mathrm{KAP}_{\mathrm{t}}+\mathrm{e}
\end{aligned}
$$

Where:

TOBQ : corporate value represented by the TobinsQ variable

CSR : disclosure of corporate social responsibility index

KI : number of institutional share ownership

KM : total ownership of managerial shares

KId : number of independent commissioners

Prf : profitability

LEV : leverage

FZ : firm size

KAP : audit quality

e : margin error

\section{Classical Assumption Test}

The ordinary least squares (OLS) method was first introduced by Carl Freidrich Gauss. The core of this method is to estimate a regression line by minimizing the sum of the squares of errors of each observation on the line. The main purpose of regression is to estimate the function of population regression based on sample regression function. The main assumptions underlying the regression model using OLS methods are normality, linearity, multicollinearity, heteroscedasticity, and autocorrelation.

\section{Normality Test}

Normal distribution assumptions are examined using the Normal Probability Plot or Histogram chart. If the data follows a normal line on the Normal Probability Plot chart then the data is assumed to be normally distributed. Another way is Testing normality is done by testing Kolmogorov- Smirnov. Testing with this method states if the value KolmogorovSmirnov has a probability greater than 0.05 , then the research variables can be stated normal distribution (Ghozali, 2001).

\section{Multicollinierity Test}

Multicollinearity is the absence of correlation of independent variables between one another. Multiple regression models must be freed from multicollinearity for one dependent variable. To detect the presence or absence of Multicollinearity in the regression model can be seen from the Tolerance and Variance Inflation Fa ctor (VIF) values. Both of these measures show each of the independent variables described by other variables. In simple terms each independent variable becomes a dependent variable and diregresi against other independent variables. In simple terms each independent variable becomes a dependent variable and diregresi against other independent variables. Tolerance measures the variability of the selected free variables that can not be explained in other independent variables. If the tolerance value greater than 0.10 or VIF is less than 10 then there is no multicollinearity (Ghozali, 2001).

\section{Autocorrelation Test}

Autocorrelation is the relationship of error penggangu that appears on the data coherent 
time (time series). In the estimation of the linear regression model contains the assumption that there is no autocorrelation between the disturbing error. Autocorrelation testing can be done by calculating Durbin-Wetson (d), by comparing the d values to dl and du. After calculating the value of the next $d$ statistics compared with the value of the table with a significant level of 5\%. Decision-making can be based on (Ghozali, 2001):

1. If the DW value is between the upper limit or upperbound (du) and (4-du), the autocorrelation correlation coefficient equals zero, meaning no autocorrelation.

2. If the DW value is lower than the lower bound (dl), then the autocorrelation coefficient is greater than zero, meaning there is positive autocorrelation.

3. If the DW value is greater than (4-dl), then the autocorrelation coefficient is smaller than zero, meaning there is negative autocorrelation.

4. If the DW value is between the upper bound (du) and the lower limit (dl) or DW is located between (4-du) and (4-dl) then the result can not be inferred.

\section{Heteroscedasticity Test}

The heterocedasticity test aims to test whether in the regression model there is a variance inequality of the residual one observation to the other. If the residual variance of one observation to another observation remains, then it is called homoscedasticity or free from heteroscedasticity. How to detect the presence or absence of heteroscedasticity is by looking at the plot graph between the predicted value of the variable bound to the residual. Detection of whether or not heteroskedastisitas can be done by looking at the presence or absence of a particular pattern on the graph sccatterplot (Ghozali, 2001).

\section{Hypothesis Testing}

After the measurement of variables in this study, then the hypotheses are tested. To perform the proposed hypothesis, it is necessary to test statistically. The data analysis is done by using multiple linear regression that is aimed to analyze the influence of corporate social responsibility and good corporate governance toward company value with profitability as moderating variable which is processed with Statistical Package for Social Science (SPSS) computer program. Hypothesis testing with multiple regression involving moderating variable can be done in three ways, namely interaction test, absolute difference test, and residual test. This study uses the test of absolute difference value. Profitability is said to be a moderating variable if the value is significantly below 0.05 .

\section{F Test}

To see the Goodness of Fit of the hypothesis testing model, it is analyzed if $F$ calculated $>\mathrm{F}$ table with a significant level of $5 \%$, it can be concluded that the model is fit. (Ghozali, 2001).

\section{T Test}

To see the effect of independent variable to the dependent variable partially used test ( one taild test ). If $\mathrm{t}$ calculated $>\mathrm{t}$ table with a significant level of 5\% then it can be concluded that partially independent variables significantly influence the dependent variable or can be done by looking at significance that is below 5\%. Conversely, if $t$ calculated $<\mathrm{t}$ table with $5 \%$ significance level, it can be concluded that partially independent variable has no significant effect on dependent variable or can be done with significant view which is above 5\% (Ghozali, 2001).

\section{Determination Coefficient Test}

Fit model test is done to find out how big the independent variable is able to explain the 
state of the dependent variable. Testing goodness of fit can be done based on the value of $\mathrm{R}^{2}$ in regression models (Ghozali, 2001).

\section{RESULTS AND DISCUSSION}

To perform the proposed hypothesis, it is necessary to test statistically. The data analysis is done by using multiple linear regression that is aimed to know the influence of corporate social responsibility and good corporate governance toward company value with profitability as moderating variable which is processed with Statistical Package For Social Science (SPSS) computer program. Hypothesis testing with multiple regression involving moderating variable can be done in three ways, namely interaction test, absolute difference test, and residual test. In this study, it uses the test of absolute difference value. Profitability is said to be a moderating variable if the value is significantly below 0.05 .

Kolmogorov-Smirnov Test Results test showed KS value of 0.577 with a significant probability level of 0,138 or $\alpha .>0.05$ Then it can be in conclude that the data is normally distributed, assuming that the regression model used satisfies the assumption of normality. Based on the test results, it is known that the model used on the independent variable has a VIF value of less than 10 or VIF <10. Thus, H0 is supported, which means the independent variables used in the equation model show no colinearity symptoms (no very strong relationship between variables independent). Thus it can be concluded that the regression model is used to avoid the problem of multicollinearity.

Based on the results of the above autocorrelation is known that TOBQ models have a total of 258 observations of 273 observations after going through the outlier test results, with the number of independent variables of 11. Then on to the lower limit value (d L) of 1.6539, with the upper limit (d U) of 1.8854. The result of the Durbin-Watson statistic was obtained for 1,899 diarea $\mathrm{d} U<\mathrm{DW}<4$ - d U, or are diarea no autocorrelation. Furthermore, in conclude that there is no positive or negative autocorrelation in regression models were used. Thus the assumption of autocorrelation in the regression model has been met.

Based on the above test results heteroskedastisitas known that there is no clear pattern, and the point - the point spread above and below the number 0 on the $\mathrm{Y}$ axis, it can be assumed not to occur heteroscedasticity in regression models were used. Based on the test, it coefficient of determination were observed through the value of $\mathrm{R}^{2}$ (r-squared) is 0,279 . This means that $27.9 \%$ of the variation of the dependent variable is the value of the Company (TOBQ) can be predicted from a combination of all independent variables, while the rest of $72.1 \%$ is explained by other factors that are not included in the research model.

Based on the test Anova or Test F, F count which can at 20.709 with a significance probability value that indicates 0,000 . A probability value of testing smaller than alpha or $\alpha$ $<0.05$ indicates that together (simultaneously) the ratio of the value of the company is able to be influenced by the CSR and corporate governance with moderation Profitability. Based on the test $\mathrm{T}$, note that:

1. H1 is supported and significant

2. $\mathrm{H} 2 \mathrm{a}$ is supportedand significant

3. H2b is not supported and not significant

4. H2c is not supported and not significant

5. H3 is supportedand significant

6. H4a is supportedand significant

7. H4b is not supported and not significant

8. $\mathrm{H} 4 \mathrm{c}$ is not supported and not significant

Disclosure of social responsibility (CSR) provides a coefficient parameter to the coefficient value of 1.311 and a significance probability value 0,034 . These results can be 
concluded that every company trying to equip items that are required in the disclosure of corporate social responsibility, the value of the company will be increased by 1.311 . This is due to the completeness of the disclosure of information about the social responsibility of companies then it will invite a positive response to investors, so investors feel confident in investing in the company that led to the increased value of the company, according to research Permanasari (2010).

Institutional stock ownership gives the value of coefficient parameters with coefficient of 0.004 and a significance probability value 0,012 . These results can be concluded that any additional proportion of institutional share ownership in the company's capital structure the company's value will be increased by 0,004 . This is because the presence of institutional share ownership then it will invite a positive response to investors, so investors feel confident in investing in the company that led to the increased value of the company, according to research Xu et al., (1997).

Based on the analysis through multiple regression analysis, the influence of the independent variables ownership managerial stock to the value of the company had test results that show the value of statistical probability (sig.) of $0.727>\alpha(0.05)$, it can be concluded hypothesis is not supported and it can be said that the partial ownership managerial shares no significant impact on the value of the company. Managerial ownership stock gives value to the parameter coefficient coefficient value of -0.002 and significance probability value of 0.727 .

In this study, an independent commissioner has a negative coefficient values indicate when independent directors increased the company's value will decline. Based on the analysis through multiple regression analysis, the effect of variable independent directors on the company's value had statistical tests that show the value of probability (sig.) of $0.084>\alpha$ (0.05), it can be concluded hypothesis is not supported and it can be said that partially independent directors are not affect the value of the company. Pengungkapan social responsibility (CSR) provides a coefficient parameter to the coefficient value of -0.003 and significance probability value 0,084 .

Based on the research results in i-level disclosure CSR manufacturing sector has a positive coefficient value of the ratio of enterprise value are moderated by the ratio of profit. This shows that if the disclosure of social responsibility and regulated by the level of corporate profits high, then the ratio of the value of the company will be higher. From the results of analysis through multiple regression analysis, the independent variables influence of Corporate Social Responsibility with moderation Return on Equity of the value of the company had test results that show the value of statistical probability (sig.) Amounted to $0.000<\alpha(0.05)$, it can be concluded that hypothesis was supportedand can said that partial social responsibility of companies with moderation earnings ratio has no significant effect on firm value. This means that the disclosure of corporate social responsibility at the time of high and low profitability of the company, affecting the value of the company, according to research Anggraini (2006).

The influence of the independent variables institutional ownership with moderation return on equity of the value of the company had test results that show the value of statistical probability (sig.) For 5,267E-005 $<\alpha(0.05)$, it can be concluded that hypothesis was supportedand it can be said that the partial ownership of the institution with moderation profit ratio has a significant effect on the value of the company. This means that institutional ownership at the time of high and low profitability of the company, affecting the value of the company, according to research Xu et al., (1997).

The influence of the independent variable good corporate governance with moderation return on equity of the value of the company had test results that show the value of statistical probability (sig.) $0,000<\alpha(0.05)$, it can be concluded hypothesis is not supported and it can 
be said that partial managerial ownership with moderation earnings ratio has no effect on firm value. This means that managerial ownership at the time of high and low profitability of the company, affecting the value of the company, according to research Xu et al., (1997).

The influence of the independent variable good corporate governance with moderation return on equity of the value of the company has statistical tests that show the value of the coefficient of $-3,809 \mathrm{E}-005$, it can be concluded hypothesis is not supported and it can be said that partially independent commissioner with moderation earnings ratio has influence significantly to the value of the company, but not in accordance with the direction of our hypotheses. This means that an independent commissioner at the time of high and low profitability of the company, give effect to the value of the company, according to research Xu et al., (1997).

\section{CONCLUSION}

Based on the analysis and discussion that has been done can be concluded as follows:

1. Corporate social responsibility

Found that the disclosure of corporate social responsibility (CSR) has influence positively to corporate value.

2. Corporate governance

a. Institutional ownership

The share ownership of the institution (KI) has a positive effect on firm value.

b. Managerial ownership

Managerial ownership (KM) has no effect on the value of the company.

c. Independent commissioner

As for the independent commissioner (KID), it has no effect on firm value.

3. CSR that is moderated by profitability

The disclosure of corporate social responsibility (CSR) that is moderated by profitability has influence on the value of the company.

4. Corporate governance that is moderated by profitability

a. Institutional ownership

The share ownership of the institution (KI) moderated by profitability has influence on the value of the company.

b. Managerial ownership

Managerial ownership (KM) moderated by profitability has no effect on firm value.

c. Independent commissioner

Finally, the independent commissioner (KID) moderated by profitability has no effect on firm value.

\section{Suggestion}

This research can indeed be said to be far from perfect so that it still needs improvement. From this research, the author suggests, if the further research on the same topic still can improve many aspects among others:

1. Make more in-depth research on what are the benefits generated by the Corporate Social Responsibility which can trigger an increase in the company's profit or related to the company's value. Due to time constraints, the sample used in this study only focuses on the manufacturing industry. Therefore, it is expected in future studies that use larger sample.

2. Due to lack of information, the samples are not divided in accordance with the related industries that are expected for the future studies. 


\section{REFERENCES}

Adams, C. A. (2002). Internal Organisational Factors Influencing Corporate Social and Ethical Reporting: Beyond Current Theorising. Accounting, Auditing and Accountability Journal, 15(2), 223-250.

Alexander, J. J., \& Buchloz. (1978). A Reason for Differences in Corporate Social Reporting. Critical Perspectives on Accounting, 10, 521-547.

Almilia, L., \& Wijayanto, D. (2007). Pengaruh Environmental Performance dan Environmental Disclosure terhadap Economic Performance, The $1^{\text {st }}$ Accounting Conference, September 2007.

Anggraini, F.R.R. (2006). Pengungkapan Informasi Sosial dan Faktor-Faktor yang Mempengaruhi Pengungkapan Informasi Sosial dalam Laporan Keuangan Tahunan (Studi Empiris pada Perusahaan-Perusahaan yang Terdaftar di Bursa Efek Jakarta). Simposium Nasional Akuntansi IX, Padang, 23-26 Agustus 2006.

Belkaoui, A., \& Karpik, P.G. (1989). Determinants of the Corporate Decision to Disclose Social Information. Accounting, Auditing \& Accountability Journal, 2(1), 36-51.

Bjuggren, P.O., Johan E.E., \& Wiberg D. (2007). Institutional Owners and Firm Performance. Working Paper, Royal Institute of Technology, Stockholm, February, 126.

Deegan, C. (2002). Introduction to the Legitimising Efect of Social and Environmental Disclosure-A Theoritical Foundation. Accounting, Auditing and Accountability Journal, 15(3), 282-311.

Downes, J. \& Goodman, J.E. (1999). Dictionary of Finance and Investment Term, Barrons Educational Series.

Elkington, J. (1998). Cannibals with Forks: The Triple Bottom Line in $21^{\text {st }}$ Century Business, Gabriola Island, BC: New Society Publishers.

Erlina. (2008). Metodologi Penelitian Bisnis untuk Akuntansi dan Manajemen. Medan: Usu Press.

Garriga, E., \& Melé, D. (2004). Corporate Social Responsibility Theories-Mapping the Territory. Journal of Business Ethics, 53, 51-71.

Ghozali, I. (2001). Statistik Non Parametrik. Semarang, Universitas Dipenogoro.

Ghozali, I. \& Chariri. (2007). Teori Akuntansi. Semarang: Badan Penerbit Undip.

Gray, R., Owen, D., \& Maunders, K. (1987). Corporate Social Reporting: Accounting and Accountability. London: Prentice-Hall.

Hackston, D., \& Milne, M. J. (1996). Some Determinants of Social and Environmental Disclosures in New Zaeland Companies. Accounting, Auditing and Accountability Journal, 9(1), 77-108.

Haigh, M., \& Jones, J.T. (2006). The Drivers of Corporate Social Responsibility: A Critical Review.

Herawaty, V. (2008). Peran Praktek Corporate Governance sebagai Moderating Variable dari Pengaruh Earnings Management terhadap Nilai Perusahaan. Jurnal Akuntansi dan Keuangan, 10(2), 97-108.

Cohen, J., Nath, L., Holder-Webb, L. \& Wood, D. (2009). "Corporate Reporting of NonFinancial Leading Indicators of Economic Performance and Sustainability", Social Science Research

Karnani, A. (2010). Failure of Libertarian Approach to Reducing Poverty. Asian Business \& Management, 1, 5-21

KPMG. (2008). International Survey of Corporate Social Responsibility.

Mathews, M. R. (1995). Social and Environmental Accounting: A Practical Demonstration of 
Ethical Concern. Journal of Business Ethics, 14, 663-671.

Murwaningsari, E. (2009). Hubungan Corporate Governance, Corporate Social Responsibilities dan Corporate Financial Performance Dalam Satu Continuum. Jurnal Akuntansi dan Keuangan, 11(1), 30-41.

Nurlela, R., \& Islahuddin. (2008). Pengaruh Corporate Social Responsibility Terhadap Nilai Perusahaan dengan Prosentase Kepemilikan Manajemen Sebagai Variabel Moderating, Simposium Nasional Akuntansi XI Pontianak.

Permanasari, W. I. (2010). Pengaruh Kepemilikan Manajemen, Kepemilikan Institusional dan Corporate Social Responsibility Terhadap Nilai Perusahaan. UNDIP. Semarang

Riyanto, E. Y., \& Linda A. T. (2007). Corporate Social Responsibility in a Corporate Governance Framework.

Roberts, R. W. (1992). Determinants of Corporate Social Responsibility Disclosure: An Application of Stakeholder Theory. Accounting, Organisations and Society, 17(6), 595612.

Retno, R. D. (2012). Pengaruh GCG dan Pengungkapan CSR terhadap Nilai Perusahaan.

Rustiarini, N. W. (2010). Pengaruh Corporate Governance pada Hubungan Corporate Social Responsibility dan Nilai Perusahaan. Simposium Nasional Akuntansi XIII Purwokerto.

Sembiring, E. R. (2003). Kinerja Keuangan, Political Visibility, Ketergantungan pada Hutang, dan Pengungkapan Tanggung Jawab Sosial Perusahaan. Simposium Nasional Akuntansi VI, Surabaya, 16 - 17 Oktober 2003.

Simon, H. \& Lindgren, F. (2009). CSR in Indonesia: A Qualitative Study from a Managerial Perspective Regarding Views and other Important Aspects of CSR in Indonesia. Student Thesis. Gotland University, Department of Business Administration.

Suharto, E. (2008). Corporate Social Responsibility: What is and Benefit for Corporate. Seminar Dua Hari, Corporate Social Responsibility: Strategy, Management and Leadership, Intipesan, Hotel Aryaduta Jakarta 13-14 Februari.

Xu, X., \& Yan, W. (1997). Ownership Structure, Corporate Governance: The Cases of Chinese Stock Company, Working Paper. 